\title{
Evaluasi Mutu Pelayanan Kefarmasian di Puskesmas Seluruh Kota Kendari
}

\section{The Evaluation of Pharmaceutical Service's Quality at Public Health Centers in Kendari}

Sunandar Ihsan ${ }^{1 *}$, Nuralifah ${ }^{1}$, Asriulah Jabar ${ }^{1}$, Sabarudin ${ }^{1}$, Fitriani Sonaru ${ }^{2}$, Rahmat Ramadhan ${ }^{2}$

${ }^{1}$ Departemen Farmakologi dan Farmasi Klinik, Fakultas Farmasi, Universitas Halu Oleo, Kendari, Indonesia

${ }^{2}$ Program Studi Sarjana, Fakultas Farmasi, Universitas Halu Oleo, Kendari, Indonesia

*Corresponding author: sunandarihsan@uho.ac.id

Submitted: 12 Juni 2020

Accepted: 2 Maret 2021

Published: 29 Agustus 2021

\begin{abstract}
Background: The purpose of service quality evaluation is to evaluate the entire series of pharmaceutical service activities and as a basis for further improvement of pharmaceutical services to improve patients' quality of life. Objective: To determine the quality of pharmaceutical services in all health centres in Kendari City based on Permenkes number 74 of 2016. Methods: This study was an observational study with a descriptive nature using a cross-sectional design. Measured service quality is patient satisfaction, dimensions of service time, and availability of the implementation of Standard Operational Procedures/SOPs. The instruments used were patient satisfaction questionnaires, interview guidelines, and observation sheets. Assessment of the quality of pharmaceutical services at the Puskesmas used is Permenkes no. 44 of 2016 concerning quality management guidelines in Puskesmas, with good categories, namely $>8.5$, sufficient $5.5-8.4$, and fewer categories, namely $<5.5$ which is obtained from the average value of four value scales on all variables. Results: The level of patient satisfaction was $79.51 \%$, which was in the sufficient category, while for the dimension of drug service time, $80 \%$ of the Community Health Centers had determined the service time for both concocted and non-concocted drugs. According to the RI Health Ministerial Regulation number 74 of 2016, only 59.04\% of health centres apply standard service procedures (SOP). In pharmacists' implementation of pharmaceutical services, it was found $43.65 \%$ on a value scale of 4 . Conclusion: Overall, average value of the quality of pharmaceutical services for all Community Health Centers in Kendari City is 6.25 (sufficient).
\end{abstract}

Keywords: community health center, Kendari, pharmaceutical services, service quality

\begin{abstract}
Abstrak
Pendahuluan: Tujuan evaluasi mutu pelayanan adalah untuk mengevaluasi seluruh rangkaian kegiatan pelayanan kefarmasian dan sebagai dasar perbaikan pelayanan kefarmasian selanjutnya sehingga meningkatkan kualitas hidup pasien. Tujuan: Penelitian ini dilakukan untuk mengetahui mutu pelayanan kefarmasian di seluruh Puskesmas di Kota Kendari berdasarkan permenkes nomor 74 tahun 2016. Metode: Penelitian ini merupakan penelitian observasional yang bersifat deksriptif menggunakan desain cross sectional. Mutu pelayanan yang diukur adalah kepuasan pasien, dimensi waktu pelayanan dan ketersediaan serta pelaksanaan Standar Operational Procedure/SOP. Instrumen yang digunakan adalah kuesioner kepuasan pasien, pedoman wawancara dan lembar observasi. Parameter penilaian mutu pelayanan kefarmasian di Puskesmas yang digunakan adalah Permenkes no. 44 tahun 2016 tentang pedoman manajemen mutu di Puskesmas, dengan kategori baik yaitu > 8,5, cukup 5,5-8,4, dan kategori kurang yaitu $<5,5$ yang didapat dari nilai rata-rata empat skala nilai. Hasil: Tingkat kepuasan pasien didapatkan $79,51 \%$ kategori cukup (skala nilai $=7$ ), sedangkan untuk dimensi waktu pelayanan obat yaitu $80 \%$ puskesmas telah menetapkan waktu pelayanan baik obat racikan maupun non racikan dengan skala nilai 7. Hanya 59,04\% (skala nilai 7) puskesmas yang menerapkan standar prosedur pelayanan (SOP) minimal sesuai permenkes
\end{abstract}


RI nomor. 74 tahun 2016. Dalam pelaksanaan pelayanan kefarmasian oleh farmasis didapatkan 43,65\% pada skala nilai 4. Kesimpulan: Secara keseluruhan rata-rata nilai mutu pelayanan kefarmasian seluruh Puskesmas di Kota Kendari adalah 6,25 atau kategori cukup.

Kata kunci: kota Kendari, mutu pelayanan, pelayanan kefarmasian, puskesmas

\section{PENDAHULUAN}

Puskesmas adalah fasilitas kesehatan tingkat pertama yang bertanggungjawab menyelenggarakan kesehatan dalam suatu wilayah (Menkes RI, 2016). Dalam penyelenggaraan kesehatan tersebut harus memperhatikan mutu layanan yang menjamin ketersediaan dan keterjangkauan obat melalui pelayanan kefarmasian. Pelaksanaan pelayanan kefarmasian tersebut, farmasis perlu menjamin mutu pelayanan yang terdiri atas manajemen perbekalan kesehatan dan pelayanan farmasi klinik yang sesuai standar minimal pelayanan kefarmasian sebagai tolok ukur pelaksanaan pelayanan kefarmasian (Menkes RI, 2016).

Pengendalian mutu pelayanan dimaksudkan untuk mencegah kesalahan pengobatan/medication error dengan menerapkan penggunaan obat yang rasional yang menjamin patient safety. Menurut (Agrawal, 2009) terdapat 1,5 juta pasien yang dirugikan akibat medication error di Amerika Serikat dan 17\% medication error akibat dispensing error yang terjadi di rumah sakit-rumah sakit di Inggris (Aldhwaihi dkk., 2016). Di salah satu rumah sakit di Yogyakarta terdapat 98,10\% medication error pada pasien stroke hemoragik (Tomm dkk., 2017). Di Kota Kendari medication error terkait rasionalitas penggunaan antibiotik di puskesmas masih belum memenuhi standar WHO (Ihsan dkk., 2017).

Untuk menjamin pelayanan kefarmasian yang sesuai standar tersebut, baik yang dilakukan di rumah sakit, apotek atau di puskesmas, maka diperlukan monitoring dan evaluasi mutu pelayanan untuk menilai capaian pelaksanaan pelayanan kefarmasian. Kualitas pelayanan di Puskesmas dapat dinilai dengan survei kepuasan pelanggan, waktu pelayanan kefarmasian dan observasi langsung pelaksanaan sistem penjaminan mutu melalui pelaksanaan pelayanan kefarmasian (Menkes RI, 2016)

Kementrian Kesehatan RI telah mengeluarkan standar pelayanan kefarmasian di Puskesmas terbaru yaitu nomor 74 tahun 2016 sebagai tolak ukur dan pedoman bagi tenaga kefarmasian dalam menyelenggarakan pelayanan kefarmasian di Puskesmas. Pengaturan standar pelayanan kefarmasian di Puskesmas bertujuan untuk meningkatkan mutu pelayanan kefarmasian (Menkes RI, 2016). Kenyataannya pelayanan kefarmasian di puskesmas masih belum maksimal yang ditandai dengan 93,94\% mutunya yang kurang (Shinta dkk., 2017). Namun di beberapa puskesmas di Bandung mutu pelayanan telah mencapai kategori sangat baik yaitu 79,53\% (Nurfitria dkk., 2017). Di Magelang penerapan standar pelayanan kefarmasian di puskesmas Kota Magelang belum sesuai standar Permenkes nomor 74 tahun 2016 (Dianita dkk., 2017).

Evaluasi pelayanan kefarmasian di Puskesmas di Sulawesi Tenggara baru dilakukan di Kabupaten Kolaka pada pengelolaan obat dan pengkajian resep (Musdalipah dkk., 2017) belum pada evaluasi mutu layanan. Untuk meningkatkan cakupan pelayanan kesehatan dan pencegahan pada medication error maka evaluasi mutu pelayanan kefarmasian dilakukan untuk mendukung tercapainya rasionalitas terapi pada pasien, dimana pengelolaan manajemen mutu yang baik akan meningkatkan cakupan pelayanan farmasi klinik pada pasien. Indikator yang dapat digunakan untuk evaluasi mutu pelayanan kefarmasian yaitu tingkat kepuasan pasien, dimensi waktu pelayanan dan pemenuhan sekaligus implementasi standar Operasional Procedure (SOP) minimal seperti yang terdapat di dalam Permenkes nomor 74 tahun 2016 (Menkes RI, 2016). Tujuan penelitian ini adalah untuk mengetahui mutu pelayanan kefarmasian berdasarkan Permenkes RI nomor 74 tahun 2016 tentang standar pelayanan kefarmasian di Puskesmas.

\section{BAHAN DAN METODE}

Penelitian ini dilakukan pada 15 puskesmas di seluruh Kota Kendari. Untuk mengukur kepuasan dilakukan pada pasien yang berkunjung ke Puskesmas serta Apoteker yang bertugas di Puskesmas untuk mengukur pelaksanaan pelayanan kefarmasian.

\section{Bahan}

Bahan penelitian berupa lembar dokumentasi dan pengumpul data. Instrumen yang digunakan adalah lembar observasi, lembar ceklist dan panduan wawancara, serta kuesioner kepuasan pasien menggunakan model service quality (servqual) yang dikembangkan oleh Parasuraman dkk, 1988 yang 
disesuaikan dengan standar pelayanan kefarmasian di puskesmas nomor 74 tahun 2016.

\section{Metode}

\section{Jenis penelitian}

Penelitian ini merupakan penelitian observasional yang bersifat deksriptif menggunakan desain cross sectional. Pengambilan data dilakukan dengan survei, observasi dokumen dan wawancara.

\section{Prosedur penelitian}

Pengambilan data dilakukan di tiap puskesmas dengan data yang diambil adalah tingkat kepuasan pasien menggunakan kuisioner pada pasien yang berkunjung yang sesuai kriteria dan setuju dengan menandatangani informed consent. Selanjutnya observasi waktu pelayanan obat racikan dan non racikan dilakukan selama satu minggu pelayanan untuk memberi keterwakilan hari pelayanan sesuai jumlah sampel yang dibutuhkan.

Observasi juga dilakukan pada dokumen Standar Operasional Prosedur/SOP di puskesmas yang dibandingkan dengan 7 buah SOP minimal yang harus ada di Puskesmas menurut standar pelayanan kefarmasian nomor 74 di Puskesmas tahun 2016.

Wawancara dilakukan pada farmasis untuk mengetahui berapa lama penetapan waktu pelayanan obat racikan dan non racikan, implementasi SOP, serta upaya ada atau tidaknya evaluasi kepuasan pasien dan tindak lanjut dari hasil evaluasi kepuasan pasien tersebut.

Tingkat kepuasan pasien digunakan model service quality (servqual) yang dikembangkan oleh Parasuraman dkk, 1988 dengan jumlah sampel yang ditetapkan berdasarkan rata-rata kunjungan pasien per hari untuk satu periode. Nilai yang didapat untuk setiap pertanyaan pada seluruh dimensi adalah 1 untuk pernyataan tidak setuju, 2 kurang setuju, 3 cukup setuju, 4 setuju dan 5 sangat setuju. Penilaian kepuasan pasien dikatakan baik jika 81 - $100 \%$ dengan skala nilai 10 , cukup jika $51-80 \%$ skala nilai 7 , kurang jika $<50 \%$ dengan skala nilai 4 (Tabel 1).

Tabel 1. Kriteria penilaian nilai indikator mutu manajemen pelayanan puskesmas

\begin{tabular}{|c|c|c|c|c|c|}
\hline \multirow[t]{2}{*}{ No } & \multirow[t]{2}{*}{ Jenis Variabel } & \multicolumn{3}{|c|}{ Skala } & Nilai Hasil \\
\hline & & Nilai $=4$ & Nilai $=7$ & Nilai $=10$ & \\
\hline 1 & $\begin{array}{l}\text { Tingkat kepuasan pasien terhadap } \\
\text { pelayanan kefarmasian di Puskesmas }\end{array}$ & $<50 \%$ & $51-80 \%$ & $81-100 \%$ & \\
\hline 2 & Penetapan dimensi waktu pelayanan obat & $<50 \%$ & $51-80 \%$ & $81-100 \%$ & \\
\hline 3 & Ketersedian SOP minimal & $<50 \%$ & $51-80 \%$ & $81-100 \%$ & \\
\hline 4 & Pelaksanaan Pelayanan Kefarmasian & $<50 \%$ & $51-80 \%$ & $81-100 \%$ & \\
\hline
\end{tabular}

Nilai mutu pelayanan dari rata-rata seluruh variabel:

Baik : $>8,5$

Cukup : $5,5-8,5$

Kurang : $<5,5$

Untuk mengetahui pelaksanaan pelayanan kefarmasian, diketahui dari pemanfaatan hasil penilaian mutu layanan sebelumnya dan pemberian umpan balik oleh Apoteker terhadap hasil evaluasi mutu layanan tersebut. Oleh karena itu untuk evaluasi pelaksanaan pelayanan kefarmasian digunakan hasil penilaian mutu layanan berupa penilaian tingkat kepuasan pasien dan adanya evaluasi dan tindak lanjut terhadap hasilnya, adanya standar prosedur pelayanan (SOP) dan pelaksanaan dari SOP tersebut, serta adanya penetapan standar dimensi waktu pelayanan dan pelaksanaannya sesuai ketetapan standar tersebut. Untuk mengetahui pelaksanaan pelayanan kefarmasian di Puskesmas digunakan lembar ceklist hasil observasi dan wawancara yang terdiri dari 13 item daftar ceklist yaitu adanya survei kepuasan pasien, kotak saran, dilakukannya evaluasi dan tindak lanjut terhadap hasil kepuasan pasien dan kotak saran, tersedianya SOP standar yaitu
SOP pemindahan obat dan bahan medis habis pakai, pelayanan obat dan bahan medis habis pakai, penyiapan dan penyerahan resep racikan, penyiapan dan penyerahan sirup kering, pelayanan informasi obat, konseling, home care, adanya standar dimensi waktu pelayanan obat racikan dan non racikan.

\section{Sampel dan kriteria sampel}

Sampel penelitian untuk mengukur kepuasan pasien dihitung berdasarkan jumlah rata-rata perhari pasien yang berkunjung di tiap-tiap puskesmas dalam satu periode. Puskesmas Abeli rata-rata/hari $=33$ orang, Puskesmas Kandai 24 orang, Puskesmas Lepo-lepo 112 orang, Puskesmas Poasia 75 orang, Puskesmas Puuwatu 111 orang, Puskesmas Benu-Benua 48 orang, Puskesmas Kemaraya 32 orang, Puskesmas Perumnas Kadia 47 orang, Puskesmas Mokoau 35 orang, Puskesmas Wua-wua 34 orang, Puskesmas mekar 49 orang, Puskesmas Jati raya 26 orang, Puskesmas Nambo 
30 orang, Puskesmas Mata 44 orang dan Puskesmas Labibia 37 orang, sehingga didapatkan jumlah sampel seluruh puskesmas adalah 737 orang. Pengambilan sampel dilakukan secara accidental dengan kriteria inklusi:

i. Laki-laki dan perempuan Pasien berumur 18 50 tahun.

ii. Bersedia menjadi responden pada penelitian ini.

iii. Pasien dalam keadaan sadar ketika menjadi responden

iv. Memahami bahasa Indonesia dengan baik dan benar

v. Berkunjung di Puskesmas minimal 2 kali

Kriteria eksklusi adalah pasien yang memerlukan bantuan untuk beraktivitas.

Untuk penilaian waktu tunggu besar sampel yang diambil adalah berdasarkan jumlah rata-rata pasien perhari selama 1 minggu untuk mewakili kunjungan pasien setiap harinya dengan jumlah rata-rata pasien 9 orang tiap puskesmas yang diambil antara jam $9-12$ sesuai rata-rata waktu pelayanan.

Untuk mengukur pelaksanaan pelayanan kefarmasian sampel yang digunakan adalah apoteker di 15 puskesmas yang mewakili 10 Kecamatan di Kota Kendari dimana 5 puskesmas dengan cakupan perawatan rawat inap dan 10 puskesmas non rawat inap.

\section{Analisis data}

Analisis data dilakukan secara deskripsi dengan menentukan skor rata-rata dari 5 dimensi kepuasan pasien dengan skor maksimal 5 tiap pertanyaan. Dimensi tersebut adalah dimensi fasilitas berwujud, dimensi kehandalan, dimensi ketanggapan, dimensi keyakinan dan dimensi empati. Skor rata-rata tiap dimensi dibandingkan dengan jumlah pertanyaan tiap dimensi untuk kemudian ditentukan nilai rata-rata keseluruhan dimensi pada keseluruhan puskesmas (sampel pasien).

Penilaian pelaksanaan pelayanan kefarmasian yaitu untuk jawaban maksimal diberi skor 2 yaitu jika terdapat item penilaian diberi nilai 1 , dan jika ada sekaligus dilaksanakan diberi nilai 2. Jika jawaban hanya salah satunya diberi skor 1 dan skor 0 jika tidak ada. Total nilai ini dihitung dibagi dengan jumlah nilai maksimal (26) dan dikali $100 \%$. Jumlah skor total yang diperoleh kemudian dibandingkan dengan skor standar pelayanan kefarmasian yang ditetapkan berdasarkan Permenkes nomor 44 tahun 2016 tentang pedoman manajemen mutu di Puskesmas, dengan kategori baik yaitu $>8,5$, cukup 5,5 - 8,4 dan kategori kurang yaitu $<5,5$. Nilai tiap kategori tersebut didapatkan dari nilai rata-rata seluruh variabel penilaian berdasarkan skala nilai yang di tetapkan seperti yang ditunjukan pada Tabel 1.

\section{HASIL DAN PEMBAHASAN}

Tingkat kepuasan pasien

Kepuasan pasien terkait dengan persepsi pasien yang didapat melalui penilaian-penilaian terhadap layanan selama melakukan interaksi dalam hal ini dengan tenaga kefarmasian. Kepuasan pasien adalah suatu tingkat perasaan pasien dari persepsi yang muncul setelah membandingkan dengan harapan pasien dari bentuk dan kinerja layanan kesehatan yang diperoleh oleh pasien. Hal ini dapat ditelusuri berdasarkan sejumlah pertanyaan terkait kondisi yang ada dan harapan yang diinginkan dalam pelayanan kefarmasian yang didapat, baik dari bentuk fisik tempat pelayanan maupun model serta kerja layanan itu sendiri. Hasil penilaian kepuasan pasien sejauh ini di Kota Kendari baru di lakukan di Apotek-apotek komunitas dan menunjukan kategori cukup (Ihsan dkk., 2014).

Kepuasan konsumen juga akan sangat bergantung pada kualitas dari pelayanan yang diberikan. Menurut Surahman 2011 dalam bukunya konsep dasar pelayanan kefarmasian berbasiskan pharmaceutical care, kualitas pelayanan terdapat beberapa dimensi yang mempengaruhinya yaitu dimensi ketanggapan, dimensi kehandalan, dimensi jaminan/keyakinan, dimensi empati dan dimensi berwujud (Gustiarini, 2016). Penilaian kepuasan pasien dikatakan baik jika 81 $100 \%$ dengan skala nilai 10 , cukup jika $51-80 \%$ skala nilai 7 , kurang jika $<50 \%$ dengan skala nilai 4 . Kepuasan pasien di seluruh Puskesmas Kota Kendari dapat dilihat pada tabel yaitu $79,51 \%$ sehingga mendapatkan nilai 7 pada kategori skala nilai.

Dibandingkan dengan tingkat kepuasan pasien di Puskesmas Baturetno Wonogiri yaitu 72,58\% (Handayani, 2016), secara keseluruhan Puskesmas di Kota Kendari tidak berbeda signifikan $(79,51)$ termasuk kepuasan pasien di tingkat apotek di Kota Kendari yaitu 76,70 (Ihsan dkk., 2014). Berbeda dengan analisis kepuasan pelayanan kesehatan secara keseluruhan (umum) di Puskesmas Palopo Makassar, pelanggan didapatkan puas dengan persentase 83,81 (Lohafri dkk., 2013). Berikut Tabel 2 merupakan tingkat kepuasan pasien di seluruh puskesmas kota Kendari. 
Tabel 2. Profil tingkat kepuasan pasien di seluruh puskesmas kota Kendari

\begin{tabular}{clcc}
\hline No. & Puskesmas & $\begin{array}{c}\text { Persentase } \\
(\%)\end{array}$ & $\begin{array}{c}\text { Interpretasi } \\
\text { (Skala Nilai) }\end{array}$ \\
\hline 1. & Abeli & 76,97 & Cukup (7) \\
2. & Benu-Benua & 78,23 & Cukup (7) \\
3. & Jati raya & 78,86 & Cukup (7) \\
4. & Kandai & 79,87 & Cukup (7) \\
5. & Kemaraya & 79,38 & Cukup (7) \\
6. & Labibia & 81,34 & Baik (10) \\
7. & Lepo Lepo & 83,07 & Baik (10) \\
8. & Mata & 76,08 & Cukup (7) \\
9. & Mekar & 77,75 & Cukup (7) \\
10. & Mokoau & 78,10 & Cukup (7) \\
11. & Nambo & 78,32 & Cukup (7) \\
12. & Perumnas & 82,02 & Baik (10) \\
13. & Poasia & 81,01 & Baik (10) \\
14. & Puuwatu & 8011 & Cukup (7) \\
15. & Wua Wua & 81,79 & Baik (10) \\
\hline & Rata-rata & 79,51 & Cukup (7) \\
\hline
\end{tabular}

\section{Dimensi fasilitas berwujud}

Fasilitas fisik yang baik dan memadai merupakan salah satu penunjang dasar dari sebuah pelayanan yang berkaitan dengan tingkat kenyamanan pasien. Hal yang dinilai pada dimensi ini adalah bukti fisik dari suatu puskesmas. Dari pertanyaan-pertanyaan terkait wujud fasilitas, pasien menyatakan baik mengenai cara pegawai puskesmas berpakaian dengan persentase tertinggi sebesar $81,57 \%$, sedangkan persentase terendah $79,59 \%$ terdapat pada indikator yang berhubungan dengan kebersihan dan kelengkapan alatalat yang dipakai dalam proses pelayanan. Dari seluruh pertanyaan terkait indikator dimensi wujud, secara keseluruhan masuk kategori cukup yaitu 80,95\%. Hal ini menunjukan dari segi penampilan dan fasilitas puskesmas-puskesmas di Kota Kendari masih perlu perbaikan. Jika dibandingkan dengan tingkat kepuasan pada dimensi fasilitas berwujud pada puskesmas Baturetno Wonogiri yang hanya mencapai $72,76 \%$ (Handayani, 2016), puskesmas-puskesmas di Kota Kendari penilaian pasien masih sedikit lebih baik. Berbeda pada kesesuaian antara harapan dan kenyataan terkait dengan dimensi berwujud, puskesmas di Palopo Makassar menunjukkan kepuasan dengan kategori baik yaitu $87,36 \%$ (Lohafri dkk., 2013).

Salah satu yang perlu diperhatikan sesuai standar pelayanan kefarmasian di Puskesmas adalah adanya ruang tunggu yang nyaman. Hasil penelitian terkait dengan kenyamanan pasien yaitu yang dirasakan pasien selama menunggu obat masuk dalam kategori cukup (77,61\%). Dalam standar pelayanan kefarmasian di puskesmas tahun 2016 juga diharuskan adanya ruang untuk melakukan konseling yang ditunjang dengan sarana informasi seperti poster, leaflet, booklet dan majalah kesehatan, dimana sebagian besar puskesmas belum memiliknya. Ketersediaan sarana pendukung pelayanan seperti alat racik yang lebih modern seperti pembuat puyer diperlukan untuk mengurangi waktu tunggu pasien. Pengunaan alat manual dapat menyebabkan pasien menunggu lama yang terbukti dengan penilaian pasien terkait pelayanan obat yang cepat, masuk dalam kategori cukup yaitu $78,95 \%$.

\section{Dimensi kehandalan}

Menurut Bustami 2011 dalam bukunya penjaminan mutu pelayanan kesehatan dan akseptabilitasnya, kehandalan adalah kemampuan memberikan pelayanan dengan segera, tepat (akurat), dan memuaskan. Berdasarkan penelitian yang dilakukan pada bagian dimensi kehandalan, diperoleh nilai tertinggi pada pertanyaan terkait kewajaran harga jual obat yaitu $82,60 \%$, sedangkan nilai terendah yaitu $75,75 \%$ pada bagian pertanyaan tentang keramahan petugas dalam melayani pasien. Secara keseluruhan puskesmas di Kota Kendari persentase rata-rata pada dimensi kehandalan masuk pada kategori cukup yaitu $78,99 \%$. Dibanding dengan sebuah Puskesmas di wilayah Cilacap pada dimensi ini didapatkan tidak jauh berbeda yaitu 72, $09 \%$ (Handayani, 2016). Jumlah persentase ini juga tidak jauh berbeda dengan salah satu puskesmas di Kota Kendari yaitu Puskesmas Mata 76,08\%.

Oleh karena itu pada dimensi kehandalan yang perlu untuk ditingkatkan adalah yang terkait dengan keramahan petugas saat melayani pasien karena memperoleh persentase yang paling rendah $(75,75)$ dari seluruh pertanyaan terkait kehandalan. Dibandingkan dengan penelitian (Lohafri dkk., 2013) di Puskesmas Palopo Makassar, keramahan petugas memiliki persentase yang tinggi $93,71 \%$. Hubungan yang baik antar manusia akan membentuk persepsi yang baik dan positif terhadap pelayanan yang diberikan. Kehandalan diperlukan untuk memberikan pelayanan kesehatan dengan tepat waktu dan akurat sesuai dengan yang ditawarkan artinya dengan kehandalan yang tinggi tenaga farmasi memilki kemampuan memberikan pelayanan yang memuaskan pasien. Apabila kinerja dibawah harapan, maka pelanggan akan kecewa, bila melebihi harapan, pelanggan akan sangat puas (Akbar \& Parvez, 2014).

\section{Dimensi ketanggapan}

Ketanggapan yaitu kemampuan petugas kesehatan menolong pelanggan dan melayani sesuai prosedur untuk memenuhi harapan pelanggan. Dimensi ini 
merupakan penilaian mutu pelayanan yang paling dinamis (Akbar \& Parvez, 2014). Berdasarkan hasil penelitian pada dimensi ini diperoleh persentase tertinggi sebesar $81,97 \%$ yaitu pertanyaan terkait dengan kemampuan pasien dalam mendapatkan informasi yang jelas dan mudah dimengerti tentang resep/obat yang ditebus, sedangkan persentase terendah $77,66 \%$ yaitu pada ketanggapan pegawai terhadap keluhan pasien. Pada keseluruhan puskesmas, persentase rata-rata pada dimensi ini masuk kategori cukup 78,92\%.

Berbeda dengan yang ditemukan oleh (Kuntoro, 2017) di sebuah puskesmas di Bantul Yogyakarta bahwa dalam pelayanan di rawat jalan ada $63 \%$ yang menyatakan puas dan $25 \%$ sangat puas. Sementara penelitian oleh (Handayani, 2016) bahwa ketanggapan dari pelayanan kesehatannya didapat $72,88 \%$. Pada suatu puskesmas di Bandung setelah implementasi jaminan kesehatan nasional/JKN dimensi ketanggapan didapatkan pada kategori baik yaitu 82,8\% (Gustiarini, 2016).

Ketanggapan berkaitan dengan kecepatan sekaligus ketepatan dalam melakukan pelayanan yang melibatkan partisipasi aktif pegawai baik dari segi kualitas fisik maupun komunikasi yang didukung dengan pengetahuan memadai sesuai prosedur. Hal ini akan mempengaruhi harapan pasien terhadap pelayanan dimana harapan ini akan dipengaruhi oleh kondisi sosial budaya pasien dengan salah satunya adalah perkembangan teknologi informasi.

\section{Dimensi keyakinan}

Keyakinan pasien akan layanan yang diberikan bermutu atau tidak berkaitan dengan kemampuan tenaga farmasi memberikan kepercayaan dan kebenaran atas pelayanan yang diberikan pada pasien. Keyakinan akan menimbulkan kepercayaan pada layanan yang diberikan. Dimensi ini ditunjukan dengan indikator pengetahuan dan keterampilan pegawai dalam bekerja, kualitas obat, dan kesesuaian obat yang diminta. Hasil penelitian didapatkan bahwa $81,46 \%$ pasien menilai baik pada pengetahuan dan keterampilan pegawai dalam bekerja, termasuk pada pada jaminan kualitas obat $(81,07 \%)$ dan kesesuaian antara obat yang diminta dengan yang didapat $(81,25 \%)$.

Secara keseluruhan rata-rata persentase pada dimensi ini pada seluruh puskesmas Kota Kendari memiliki penilaian yang baik yaitu $81,25 \%$. Dimensi ini merupakan dimensi dengan presentase terbaik dari lima dimensi yang ada. Dimensi ini sangat penting, karena melibatkan pasien terhadap kemampuan penyedia pelayanan dan kepuasan pasien (Akbar \& Parvez, 2014). Penelitian oleh (Handayani, 2016) tingkat jaminan keyakinan pasien terhadap pelayanan kesehatan secara umum didapat lebih rendah yaitu 72,22\%. Berbeda dengan dimensi yang diungkapkan oleh (Lohafri dkk., 2013) bahwa keyakinan berhubungan dengan kesiapan sistem mencakup kesigapan petugas dalam melayani dengan prosedur yang jelas dan menunjukan kesesuaian harapan dan kenyataan yang tinggi yaitu 95,71\%. Sementara di Bandung setelah implementasi JKN dimensi keyakinan didapat 79,1\% (Gustiarini, 2016).

\section{Dimensi empati}

Empati adalah memberikan perhatian penuh kepada pasien yang meliputi perhatian kepada pasien, pemahaman akan kebutuhan pasien, perhatian terhadap kepentingan pasien, kesesuaian waktu pelayanan dengan kebutuhan pasien. Berdasarkan penelitian yang dilakukan, diperoleh persentase tertinggi sebesar $80,90 \%$ pada indikator pelayanan kepada semua pasien tanpa memandang status sosial, sedangkan persentase terendah yaitu $76,52 \%$ pada indikator kenyamanan pasien selama menunggu obat. Secara keseluruhan pada dimensi ini masuk kategori cukup 78,54\%. Dimensi ini merupakan dimensi yang memilki persentase terendah dari kelima dimensi yang ada sehingga perlu ditingkatkan, karena dimensi ini berkaitan dengan kesadaran diri pegawai yang dibangun melalui keterampilan komunikasi yang melibatkan perasaan peduli, ketulusan dan keikhlasan dalam melayani pasien serta kompetensi yang memadai. Penilaian kepuasan terhadap jasa pelayanan yang diterima mengacu pada beberapa faktor salah satunya yaitu komunikasi, dimana komunikasi yang baik adalah yang pelibatan diri secara utuh dan penuh dari komunikator. Pada dimensi empati dibanding dengan hasil yang didapatkan oleh (Handayani, 2016) 72,89\% hal ini tidak jauh berbeda. Penelitian yang didapatkan oleh (Lohafri dkk., 2013) kesesuaian antara harapan dan kenyataan pada dimensi empati didapatkan tinggi yaitu $95,01 \%$ yang menunjukan empati yang diberikan oleh petugas sesuai dengan yang diharapkan pasien. Hal berbeda ditemukan oleh (Kuntoro, 2017) bahwa $67 \%$ menyatakan puas dan hanya $17 \%$ menyatakan sangat puas pada sikap empati petugas pelayanan. Oleh karena itu kekuatan pelayanan yang baik salah satunya terletak pada sikap empati petugas yang mempengaruhi kenyamanan pasien selama berada di fasilitas kesehatan. Dibanding dengan puskesmas di Bandung setelah implementasi JKN dimensi empati didapatkan cukup yaitu $67,8 \%$ (Gustiarini, 2016). 


\section{Dimensi waktu pelayanan}

Dimensi waktu adalah lama pelayanan obat yang dimulai dari pasien menyerahkan resep sampai pasien menerima obat dan informasi obat. Suatu pelayanan farmasi dikatakan baik apabila lama pelayanan obat dari pasien menyerahkan resep sampai pasien menerima obat dan informasi obat tidak terlalu lama dan juga tidak dalam waktu singkat. Hal tersebut mempengaruhi loyalitas pelanggan karena berhubungan dengan kepuasan pelanggan (Akbar \& Parvez, 2014). Penetapan dimensi waktu dalam pelayanan obat dimaksudkan agar pasien merasa nyaman dan tidak menunggu lama. Untuk mengetahui dimensi waktu pelayanan obat yang ditetapkan oleh Puskesmas, maka dilakukan pengukuran secara langsung dengan mengacu pada standar waktu yang ditetapkan oleh puskesmas itu sendiri dan wawancara kepada apoteker pengelola apotek.

Terdapat puskesmas yang tidak menetapkan dimensi waktu pelayanan obat racikan maupun non racikan karena puskesmas tersebut belum mempunyai apoteker penanggung jawab di apotek pada saat penelitian ini dilakukan. Hal ini perlu mendapat perhatian karena menteri Kesehatan dalam PMK no 74 tahun 2016 tentang standar pelayanan kefarmasian di Puskesmas menyatakan bahwa puskesmas minimal memiliki satu orang apoteker penanggungjawab (Menkes RI, 2016). Waktu pelayanan juga dapat dipengaruhi oleh banyaknya pasien yang dilayani dimana rasio pasien dan farmasis di puskesmas Kota Kendari adalah 1 : > 50 orang, sehingga dalam Peraturan menteri kesehatan RI No.74 tahun 2016 juga di tetapkan bahwa puskemas harus memilki satu apoteker untuk 50 pasien. Tabel 3 berikut merupakan data rata-rata waktu pelayanan obat racikan, non racikan, dan jumlah puskesmas yang menetapkan standar waktu pelayanan di puskesmas-puskesmas kota Kendari.

Tabel 3. Rata-rata waktu pelayanan obat racikan dan non racikan dan jumlah puskesmas yang menetapkan standar waktu pelayanan di puskesmas-puskesmas kota Kendari

\begin{tabular}{|c|c|c|c|}
\hline \multirow{2}{*}{ No. } & \multirow{2}{*}{ Puskesmas } & \multicolumn{2}{|c|}{ Rata-rata waktu pelayanan obat } \\
\hline & & Obat racikan & Obat non racikan \\
\hline 1. & Abeli & 12 menit (tdk ada standar) & 6 menit (tdk ada standar) \\
\hline 2. & Benu-Benua & 9 menit (tdk ada standar) & 6 menit (tdk ada standar) \\
\hline 3. & Jati raya & 8 menit (standar 10 menit) & 3 menit (standar 5 menit) \\
\hline 4. & Kandai & 9 menit (standar 15-20 menit) & 6 menit (standar 5-10 menit) \\
\hline 5. & Kemaraya & 11 menit (standar 10-15 menit) & 5 menit (standar 5-10 menit) \\
\hline 6. & Labibia & 12 menit (standar $10-15$ menit) & 4 menit (standar 5-10 menit) \\
\hline 7. & Lepo Lepo & 10 menit (standar 15 menit) & 6 menit (standar 10 menit) \\
\hline 8. & Mata & 13 menit (standar 10 menit) & 5 menit (standar 5 menit) \\
\hline 9. & Mekar & 7 menit (standar 8 menit) & 5 menit ( 8 menit) \\
\hline 10. & Mokoau & 7 menit (standar 3 menit) & 4 menit (standar 2 menit) \\
\hline 11. & Nambo & 6 menit (standar 4 menit) & 3 menit (standar 3 menit) \\
\hline 12. & Perumnas Kadia & 11 menit (tidak ada standar) & 4 menit (tidak ada standar) \\
\hline 13. & Poasia & 11 menit (standar 30 menit) & 7 menit (standar 20 menit) \\
\hline 14. & Puuwatu & 10 menit (standar 5-15 menit) & 8 menit (standar 5-10 menit) \\
\hline \multirow[t]{2}{*}{15.} & Wua Wua & 10 menit (standar $\leq 30$ menit) & 4 menit (standar $\leq 15$ menit) \\
\hline & Rata-rata & 9,73 menit & 5,06 menit \\
\hline
\end{tabular}

Hasil pengamatan menunjukan sebanyak 12 puskesmas $(80 \%)$ telah menetapkan dimensi waktu pelayanan obat dan 3 Puskesmas (20\%) tidak menetapkan dimensi waktu pelayanan obat. Berdasarkan jumlah puskesmas yang menetapkan waktu pelayanan obat maka pada indicator penetapan dimensi waktu dengan skala nilai 4. Puskesmas yang menetapkan dimensi waktu pelayanan obat artinya puskesmas tersebut memilki standar waktu pelayanan obat, mulai dari penerimaan resep sampai penyerahan obat dan pemberian informasi tentang obat yang diterima pasien.

Waktu pelayanan resep dapat dipengaruhi oleh tindakan pemeriksaan kelengkapan administrasi resep, pemeriksaan klinis dan kelengkapan pemberian informasi obat pada saat menyerahkan obat pada pasien. Penemuan oleh (Shinta dkk., 2017) di Puskesmas Kabupaten Banyumas bahwa tidak ada satupun puskesmas yang melakukan pemeriksaan administrasi resep, dan pertimbangan klinis dilakukan hanya pada 
medikasi rangkap sedangkan informasi obat hanya pada cara dan lama pemakaian obat. Keberadaan Apoteker seharusnya berpengaruh terhadap waktu pelayanan terkait dengan keahlian dalam melakukannya yang dimulai dari menyiapkan obat sampai memberikan informasi obat, namun penelitian (Shinta dkk., 2017) menemukan keberadaan apoteker tidak mempengaruhi keseluruhan mutu layanan.

\section{Ketersediaan standar prosedur pelayanan (SOP)}

Standar prosedur pelayanan (SOP) merupakan suatu tata cara atau kegiatan untuk menyelesaikan pekerjaan dengan urutan waktu dan memiliki pola kerja yang tetap yang telah ditentukan guna menjamin mutu pelayanan sesuai standar yang telah ditetapkan. Standar Prosedur pelayanan (SOP) minimal untuk Puskesmas yang telah direkomendasikan oleh Kementerian Kesehatan RI berdasarkan standar pelayanan kefarmasian nomor 74 tahun 2016 terdiri atas 7 kegiatan yaitu standar prosedur pelayanan atau SOP untuk proses pemindahan obat dan bahan medis habis pakai, proses pelayanan obat dan bahan medis habis pakai, proses penyiapan dan penyerahan resep racikan, proses penyiapan dan penyerahan sirup kering, proses pelayanan informasi obat, proses konseling, dan proses pelayanan. Distribusi frekuensi jumlah SOP yang dimiliki seluruh puskesmas di kota Kendari dapat dilihat pada Tabel 4 berikut.

Tabel 4. Distribusi frekuensi jumlah SOP yang dimiliki seluruh puskesmas di kota Kendari

\begin{tabular}{clcc}
\hline No. & Puskesmas & $\begin{array}{c}\text { Ketersediaan } \\
\text { SOP }\end{array}$ & $\begin{array}{c}\text { Persentase } \\
(\%)\end{array}$ \\
\hline 1. & Abeli & - & 0 \\
2. & Benu-Benua & 7 & 100 \\
3. & Jati raya & - & 0 \\
4. & Kandai & 6 & 85,71 \\
5. & Kemaraya & 5 & 71,42 \\
6. & Labibia & 7 & 100 \\
7. & Lepo Lepo & 7 & 100 \\
8. & Mata & - & 0 \\
9. & Mekar & 3 & 42,85 \\
10. & Mokoau & 5 & 71,42 \\
11. & Nambo & 5 & 71,42 \\
12. & Perumnas & 5 & 71,42 \\
13. & Poasia & 4 & 57,14 \\
14. & Puuwatu & 3 & 42,85 \\
15. & Wua Wua & 5 & 71,42 \\
\hline & Rata-Rata & $59,04 \%$ (skala nilai $=7$ ) \\
\hline
\end{tabular}

Hasil penelitian seperti pada tabel 4 menunjukkan bahwa hanya 59,04\% (skala nilai $=7$ ) puskesmas yang memiliki SOP lengkap. Dari 15 puskesmas hanya 12 puskesmas yang memiliki dokumen SOP dan 3 puskesmas yang tidak memilki dokumen SOP. Dari 12 puskesmas tersebut, terdapat 3 puskesmas yang memiliki semua dokumen standar prosedur pelayanan (SOP), 1 puskesmas yang memiliki 6 dokumen standar prosedur pelayanan (SOP), 5 puskesmas yang hanya memliki 5 dokumen standar prosedur pelayanan (SOP), satu puskesmas yang hanya memilki 4 dokumen standar prosedur pelayanan (SOP) dan 2 puskesmas yang memilki 3 dokumen standar prosedur pelayanan (SOP).

Masih ditemukannya Puskesmas yang tidak memliki dokumen standar prosedur pelayanan (SOP) menunjukan pelaksanaan pelayanan kefarmasian baik pengelolaan sediaan farmasi dan bahan habis pakai dan pelayanan farmasi klinik belum berjalan maksimal. Hal ini disebabkan karena pelaksanaan pelayanan kefarmasian yang bermutu memperhatikan beberapa hal yaitu unsur masukan berupa sumber daya dan ketersediaan SOP yang harusnya dibuat oleh kepala Puskesmas, unsur proses yaitu komunikasi dan kerjasama antara tenaga kesehatan dan dengan Kepala puskesmas khususnya dalam penyediaan SOP pelayanan kefarmasian serta unsur lingkungan yaitu kebijakan dan manajemen oleh Kepala puskesmas.

Penelitian oleh Sinta LH dkk menemukan bahwa hanya $64 \%$ puskesmas yang memiliki SOP di seluruh Kabupaten Banyumas dan tidak ada satupun puskesmas yang memiliki SOP lengkap (Shinta dkk., 2017). Adanya SOP ini penting untuk menjamin pelayanan yang jelas dan tidak berbelit-belit yang sangat di inginkan oleh masyarakat yang datang berobat ke puskesmas yang mempengaruhi kepuasan pasien terhadap pelayanan yang diberikan (Nurba, 2012). Tidak terdapatnya SOP pelayanan di Puskesmas dapat menyebabkan kualitas pelayanan tidak sesuai standar pelayanan minimal. Manfaat adanya standar prosedur pelayanan (SOP) adalah untuk memastikan bahwa praktek yang baik dapat tercapai setiaap saat, untuk menstandarkan bentuk pelayanan sesuai yang ditetapkan, untuk melindungi profesi dalam menjalankan praktek kefarmasian, adanya pembagian tugas dan wewenang bagi petugas, dapat memberikan pertimbangan dan panduan untuk tenaga kesehatan lain yang bekerja di apotek puskesmas, dapat digunakan sebagai alat melatih staf baru dan dapat membantu proses audit (Menkes RI, 2016).

\section{Pelaksanaan pelayanan kefarmasian}

Pelayanan kefarmasian merupakan suatu pelayanan langsung dan bertanggung jawab kepada pasien yang berkaitan dengan sediaan farmasi dengan maksud mencapai hasil yang pasti untuk meningkatkan mutu kehidupan pasien. Penilaian mutu layanan kefarmasian 
adalah untuk mencegah masalah terkait obat/medication error, dengan tujuan patient safety (Menkes RI, 2016). Oleh karena itu penilaian mutu pelyanan kefarmasian dapat dilakukan dengan evaluasi dan monitoring pada pelaksanaan SOP yang merupakan bagian dari pelayanan farmasi klinik berupa monitoring pada pelayanan resep dan pelayanan pasien. Adapun evaluasi penggunaan obat adalah terkait dengan audit klinis (Menkes RI, 2016). Pengukuran mutu layanan kefarmasian yang mencakup penilaian kegiatan farmasi klinik tersebut dilakukan melalui pengamatan pada kepuasan pasien seperti tampak pada penilaian dimensi reabilitas, keyakinan dan empati. Dengan demikian pelayanan farmasi klinik digambarkan melalui penilaian indeks kepuasan pasien dan penetapan dimensi waktu juga penetapan dan pelaksanaan SOP yang dilakukan oleh apoteker sebagai pelaksanaan pelayanan kefarmasian. Distribusi frekuensi pelayanan kefarmasian diperoleh dari persentase 13 item daftar ceklist yang telah disusun melalui hasil observasi dan wawancara pada setiap puskesmas seperti pada Tabel 4.

Pada Tabel 4 menunjukan bahwa pelaksanaan pelayanan kefarmasian di puskesmas-puskesmas Kota Kendari masih kategori kurang dengan persentase $43,65 \%$ yaitu pada skala nilai 4 . Hal ini menunjukan apoteker yang bertanggung jawab di Puskesmas tersebut dalam menjalankan fungsinya dalam pelayanan kefarmasian di puskesmas yang dikelolanya belum memenuhi standar pelayanan kefarmasian nomor 74 tahun 2016.

Pelaksanaan pelayanan kefarmasian yang masih kurang ini dilihat dari penetapan dan pelaksanaan SOP yang masih kurang, pelaksanaan survei dan evaluasi hasil survei kepuasan konsumen dan penetapan standar waktu pelayanan obat racikan dan non racikan atau sirup kering.

Terdapat satu puskesmas yang tingkat pelayanan kefarmasiannya kategori baik $84,61 \%$ dimana hanya indikator pelaksanaan survei dan evaluasi hasil survei kepuasan pasien dan tindak lanjutnya yang tidak dilakukan. Pelaksanaan pelayanan kefarmasian baik pengelolaan sediaan farmasi dan bahan medis habis pakai serta pelayanan farmasi klinik dilakukan untuk memenuhi standar mutu pelayanan kefarmasian menurut PMK nomor 74 tahun 2016 tentang standar pelayanan kefarmasian di puskesmas.

Untuk memenuhi standar pelayanan kefarmasian tersebut dapat dilakukan dengan evaluasi capaian pelayanan kefarmasian dengan cara audit klinis serta review atau pengkajian pelaksanaan pelayanan kefarmasian berupa kajian penggunaan obat antibiotik, pelaksanaan konseling, pelayanan informasi obat atau home care (Menkes RI, 2016). Hal ini perlu dilakukan karena pelaksaanaan pelayanan kefarmasian terkait pelayanan farmasi klinik di puskesmas masih kurang seperti yang ditemukan oleh (Shinta dkk., 2017) menunjukan bahwa tidak ada satupun puskesmas di kabupaten Banyumas yang melakukan home care, dan konseling. Di salah satu Puskesmas Kabupaten Magelang yang melakukan konseling hanya 56,14\%, sedangkan PIO masih di lakukan oleh tenaga teknis kefarmasian (Dianita dkk., 2017).

Pelaksanaan pelayanan kefarmasian yang belum sesuai standar menunjukan bahwa pelayanan kefarmasian di puskesmas-puskesmas Kota Kendari saat ini masih kurang sehingga mutu pelayanan perlu ditingkatkan agar memenuhi standar pelayanan kefarmasian di Puskesmas sesuai standar dari Kemenkes RI nomor 74 tahun 2016. Berikut Tabel 5 yang menyajikan distribusi frekuensi pelaksanaan pelayanan kefarmasian di seluruh puskesmas kota Kendari.

Tabel 5. Distribusi frekuensi pelaksanaan pelayanan kefarmasian di seluruh puskesmas kota Kendari

\begin{tabular}{clcc}
\hline No. & Puskesmas & $\begin{array}{c}\text { Persentase } \\
(\%)\end{array}$ & Interpretasi \\
\hline 1. & Abeli & 7,69 & Kurang \\
2. & Benu-Benua & 61,53 & Cukup \\
3. & Jati raya & 15,38 & Buruk \\
4. & Kandai & 61,53 & Cukup \\
5. & Kemaraya & 69,23 & Cukup \\
6. & Labibia & 76,92 & Cukup \\
7. & Lepo Lepo & 84,61 & Baik \\
8. & Mata & 19,23 & Kurang \\
9. & Mekar & 46,15 & Kurang \\
10. & Mokoau & 46,15 & Kurang \\
11. & Nambo & 50,00 & Kurang \\
12. & Perumnas & 38,46 & Kurang \\
13. & Poasia & 61,53 & Cukup \\
14. & Puuwatu & 46,15 & Kurang \\
15. & Wua Wua & 76,92 & Cukup \\
\hline \multicolumn{5}{l}{ Rata-rata } & $43,65($ skala nilai $=4)$ \\
\hline
\end{tabular}

\section{KESIMPULAN}

Mutu pelayanan kefarmasian di seluruh puskesmas kota kendari adalah kategori cukup dengan rata-rata skala nilai 6,25 yaitu tingkat kepuasan pasien 79,51\% (skala nilai 7), penetapan dimensi waktu pelayanan obat $80 \%$ (skala nilai 7), dan adanya dokumen standar prosedur pelayanan (SOP) 59,04\% (skala nilai 7) serta pelaksanaan pelayanan kefarmasian di seluruh puskesmas kota Kendari adalah 43,65\% skala nilai 4. 


\section{UCAPAN TERIMA KASIH}

Penulis mengucapkan terima kasih kepada Kepala dinas Kesahatan Kota Kendari, dan seluruh kepala puskesmas kota Kendari yang tela memberikan izin penelitian, serta kepada seluruh apoteker/asisten apoteker dan responden di puskesmas Kota Kendari yang telah bersedia menjadi objek penelitian ini.

\section{DAFTAR PUSTAKA}

Agrawal, A. (2009). Medication Errors: Prevention Using Information Technology Systems. British Journal of Clinical Pharmacology; 67; 681-686.

Akbar, M. M. \& Parvez, N. (2014). Impact of Service Quality, Trust, and Customer Satisfaction on Customer Loyalty. Pakistan Journal of Commerce and Social Sciences; 8; 331-354.

Aldhwaihi, K., Umaru, N., Pezzolesi, C. \& Schifano, F. (2016). A Systematic Review of the Nature of Dispensing Errors in Hospital Pharmacies. Integrated Pharmacy Research and Practice; 5; 1 10.

Dianita, P. S., Kusuma, T. M. \& Septianingrum, N. M. A. N. (2017). Evaluasi Penerapan Standar Pelayanan Kefarmasian di Puskesmas Kabupaten Magelang Berdasarkan Permenkes RI No.74 Tahun 2016. University Research Colloquium (URECOL); 74; 125-134.

Gustiarini. (2016). Analisis Mutu Pelayanan Kesehatan di Puskesmas Kota Bandung Setelah Implementasi Kebijakan Jaminan Kesehatan Nasional. SCIENTICA; 3; 46-68.

Handayani, S. (2016). The Level of Patient Satisfaction with Health Services in Baturetno Health Centers. Profesi (Profesional Islam) Media Publikasi Penelitian; $14 ; 42$.

Ihsan, S., Leorita, M., Sitti, A., Syukriadi, Z. \& Ibrahim, M. H. (2017). Evaluasi Rasionalitas Penggunaan Obat Ditinjau dari Indikator Peresepan Menurut World Health Organization ( WHO ) di Seluruh Puskesmas Kota Kendari Tahun 2016. 5, 402-
409.

Ihsan, S., Rezkya, P., \& Akib, N. I. (2014). Evaluasi Mutu Pelayanan dan Hubungan Antara Kepuasan Konsumen dan Pelaksanaan Pelayanan Kefarmasian oleh Apoteker Pengelola Apotek di Kota Kendari. Medula; 2; 119-125.

Kuntoro, W. (2017). Kepuasan Pasien Terhadap Kualitas Pelayanan di Tempat Pendaftaran Pasien Rawat Jalan Puskesmas Kretek Bantul Yogyakarta. Jkesvo (Jurnal Kesehatan Vokasional; 2; 140-147.

Lohafri, T., Indar \& Darmawansyah. (2013). Analisis Tingkat Kepuasan Pasien di Puskesmas Bara Permai Kota Palopo Analysis. Jurnal AKK; 2; $15-$ 21.

Menkes RI. (2016). Standar Pelayanan Kefarmasian di Puskesmas nomor 74 tahun 2016. Jakarta: Menkes RI.

Musdalipah, Saehu, M. S. \& Asmiati. (2017). Analisis Pelayanan Kefarmasian di Puskesmas Tosiba Kabupaten Kolaka. Warta Farmasi; 6; 23-31.

Nurba. (2012). Analisis Tingkat Kepuasan Pelayanan Publik pada Puskesmas Loa Janan. Eksis; 8; 2298-2308.

Nurfitria, R. S., Priyadi, A. \& Sepriantina (2017). Evaluation of Drug Management and Service Quality of Several Public Primary Health Care Pharmacies in Bandung. Acta Pharmaceutica Indonesia; 42; 9-17.

Shinta, R., Hanggara, L., Gibran, N. C. \& Kusuma, A. M. (2017). Pengaruh Keberadaan Apoteker terhadap Mutu Pelayanan Kefarmasian di Puskesmas Wilayah Kabupaten Banyumas. Jurnal Kefarmasian Indonesia; 363; 67-76.

Tomm, T. B., Akrom, A., \& Jatiningrum, A. (2017). Gambaran Medication Error pada Fase Prescribing dan Administrasi pada Pengobatan Stroke di IGD Rumah Sakit X di Yogyakarta. Pharmaciana; 7; 25-32. 